\title{
DEVELOPMENT OF COMPOSITE SALT CORES FOR FOUNDRY APPLICATIONS
}

\author{
RAZVOJ KOMPOZITNIH SLANIH JEDER ZA UPORABO V \\ LIVARSTVU
}

\author{
Jaroslav Beňo, Eliška Adámková, František Mikšovský, Petr Jelínek \\ VŠB-Technical University of Ostrava, Faculty of Metallurgy and Materials Engineering, Department of Metallurgy and Foundry, \\ 17. listopadu 15/2172, 70833 Ostrava-Poruba, Czech Republic \\ jaroslav.beno@vsb.cz
}

Prejem rokopisa - received: 2013-09-26; sprejem za objavo - accepted for publication: 2014-09-05

\author{
doi: $10.17222 / \mathrm{mit} .2013 .160$
}

\begin{abstract}
For the purpose of increasing the physical/mechanical properties of the cores based on inorganic salts generally destined for pre-casting the cavities and holes of the castings from non-ferrous alloys, the composite salt matrixes are preferably used. The base salt is enriched with the materials of defined properties (granulometry, heat resistance, cooling effect, heat conductivity) This contribution aims at determining the influences of individual additives on the behaviour of the cores prepared with different methods (shooting and squeezing) during a production of the castings with a high surface quality of the pre-cast holes.

Keywords: non-ferrous alloys, salt cores, inorganic salts, die casting, PUR Cold Box, Warm Box, core solubility and stability
\end{abstract}

Zaradi naraščajočih fizikalno-mehanskih lastnosti jeder na osnovi anorganskih soli se za jedra, najpogosteje namenjena za predhodno litje votlin in praznin v ulitkih iz neželeznih zlitin, uporabljajo kompoziti z osnovo iz soli. Osnovna sol je obogatena z materiali z določenimi lastnostmi (zrnatost, toplotna odpornost, učinek ohlajanja, toplotna prehodnost). Namen tega prispevka je določiti vpliv posameznih dodatkov na vedenje jeder, pripravljenih po različnih metodah (s streljanjem in $\mathrm{z}$ brizganjem) med izdelavo ulitkov z veliko kvaliteto površine in predizdelanih odprtin.

Ključne besede: neželezne zlitine, slana jedra, anorganske soli, tlačno litje, PUR Cold Box, Warm Box, topnost jeder in stabilnost

\section{INTRODUCTION}

The application of salt cores for the pre-casting of casting cavities and holes has been known since the $1970 \mathrm{~s}^{1}$. In the course of time this technology has found its application, above all, in the field of the large-lot production of the castings from Al-alloys (cooling channels of engine pistons) manufactured with the gravity and low-pressure casting methods ${ }^{2}$.

The application of the cores based on water-soluble inorganic salts represents a bonding system associated with easy cleaning of even geometrically complex pre-cast holes, ensuring a dimensional and form complexity and a smoothness of the pre-cast holes of castings. In addition, this binder system is friendly to the living environment and technological equipment. The cores can be manufactured in a closed ecological cycle. During the casting, cooling and solidification the salt cores do not emit any VOC emissions.

The casting process using an increased pressure all the time represents the predominant technology for manufacturing the castings from non-ferrous alloys $\mathrm{s}^{3,4}$ (primarily the use of metal cores). With the growing shape complexity of the castings the requirements for the cleanability of pre-cast cavities and holes are escalating. The application of the cores based on inorganic salts can be a solution of this problem.
Meeting this highly demanding requirement, the application of the cores for the high-pressure casting process (die casting) is complicated due to the extreme conditions to which a core is exposed. The issues that need to be considered are, above all, a high rate of the mold filling leading to the erosion of the cores, metal penetration and a loss of dimensional accuracy under the influence of a closeness of the temperatures of the cast alloys and salt melting.

For these reasons the cores made only of a salt matrix can be replaced with the so-called composite salt cores where the base salt matrix is enriched with the additives with specific properties.

The use of composites, including the additives with a defined granulometry, is aimed at the growth of the primary and secondary strengths that used to be explained with the erosion of long dislocation lines present in a salt matrix with finely dispersed particles (of a high heat resistance). As the melting temperature of the cores from pure salts is near the melt temperatures, the addition of additives increases the heat resistance of the cores, decreasing the possibility of the surface defects of castings. Their influence on the surface quality of castings is also augmented by a higher cooling effect of the cores as a result of the presence of the additives.

The addition of the additives further improves the dimensional and form accuracy, it keeps a good bench 


\section{J. BEŇO et al.: DEVELOPMENT OF COMPOSITE SALT CORES FOR FOUNDRY APPLICATIONS}

life of the cores and it does not negatively influence their solubility in water.

The properties of the salt cores can be further modified and optimized for individual casting methods by changing the preparation conditions (the intensity of the squeezing pressures, the temperature of the injection in the core box, the choice of a binder, etc.) and the base matrix composition (the salt type, the additives), suitable for the pre-casting of hardly accessible cavities and holes of complex forms.

At present there are many methods of core manufacturing; two processes of manufacturing salt cores were developed in our workshop - high-pressure squeezing with the utilization of the recrystallization process where the strength is achieved by sticking moistened salt grains together and the recrystallization along the grain boundaries, and shooting with the use of inorganic binders, e.g., alkali silicates.

This contribution is aimed at determining the influences of individual additives on the behavior of the cores prepared with different methods (shooting and squeezing) during the production of the castings with a high surface quality of the pre-cast holes.

\section{MATERIALS AND METHODS}

Salt cores based on chemically pure salt (chloride, marked as $\mathrm{KCl}$ ) and technical salt (chloride, marked as $\mathrm{NaCl}$ ) and different additives (marked as $\mathrm{A}, \mathrm{B}, \mathrm{C}$ ) with the basic parameters summarized in Table $\mathbf{1}$ were used as the test cores.

Aluminum alloy AlSi9Cu3(Fe) was used for the experiments. The test casting was cast in operational conditions of the joint-stock company of KOVOLIS HEDVIKOV a. s., CZ, on a casting machine CLH 400 with a squeezing pressure of $76.8 \mathrm{MPa}$, in a chamber under a casting temperature of $690{ }^{\circ} \mathrm{C}$

The cores were prepared in two ways as follows:

\section{i) method of high-pressure squeezing of the salts}

The cores were squeezed from a mildly moistened composite salt matrix (up to $1 \%$ ) with a loading rate of $9 \mathrm{kN} / \mathrm{s}$. The cores were strengthened due to the mechanical deformation of the grains (a conglomeration) and the recrystallization along the grain boundaries. The primary strengths (cold), the strength under high temperatures $\left(650{ }^{\circ} \mathrm{C}\right)$ and the residual (secondary) cold strength after the thermal exposure $\left(650{ }^{\circ} \mathrm{C}, 1 \mathrm{~h}\right)$ were determined. The primary strengths were evaluated $48 \mathrm{~h}$ after the squeezing, but only when the second phase of the hardening - the recrystallization of the salt grain boundaries - was in place;

\section{ii) injection into core boxes using binders}

A mixture of the composite crystalline salt (finely ground and of the original granulometry) and the binder (Na-silicate, $M=1.84$ ) was compacted by being injected (7.5-8 bar) into a warm core box $\left(190{ }^{\circ} \mathrm{C}\right)$ with an injection rate of $7.5 \mathrm{~s}$ and a hardening time of $50 \mathrm{~s}$. The shooting machine of the MOREK (PL) firm was used for the injection.

The main criterion was the bending strength $\sigma_{\mathrm{o}}$ measured on an adapted universal apparatus LRu-2e (MULTISERVIS MOREK, PL).

The seeming porosity $m$ of the samples of the salt cores was determined according to:

$$
m=\frac{\rho_{\mathrm{K}}-\rho_{\text {core }}}{\rho_{\mathrm{K}}} \cdot 100(\%)
$$

where:

$m$ - porosity $(\%)$

$\rho_{\mathrm{K}}-$ density of matrix $\mathrm{KCl}\left(1.981 \mathrm{~g} / \mathrm{cm}^{3}\right)$

$\rho_{\text {core }}-$ density of the core $\left(\mathrm{g} / \mathrm{cm}^{3}\right)$

The roughness tests of the pre-cast holes were done according to the ISO 1997 standard; a roughness meter of SurfTest SJ-301-Mitutoyo was used. Ten measurements were done for each sample and the resulting value of the mean arithmetic roughness $-R_{\mathrm{a}}(\mu \mathrm{m})-$ was obtained as the average of these measurements. Before the testing the castings were fettled of possible coating residues.

Table 1: Basic parameters of used additives

Tabela 1: Osnovni parametri uporabljenih dodatkov

\begin{tabular}{|c|c|c|}
\hline Additive & mode $d_{50} / \mu \mathrm{m}$ & SPAN \\
\hline A & 28.825 & 2.136 \\
\hline B & 130.875 & 4.844 \\
\hline C & 158.033 & 0.736 \\
\hline
\end{tabular}

Note: SPAN - width of the granulometric curve

\section{RESULTS AND DISCUSSION}

\subsection{Injection into core boxes using binders}

For the purpose of making cores with more complex forms, the manufacturing technology for salt cores using an injection into warm core boxes was developed. Beside the shape complexity, another expected advantage is the utilization of the existing plants for manufacturing sand cores. The method requires a suitable choice of the binder (of an inorganic or organic type) for achieving high strengths (above all, under a high temperature) and an easy solubility in water after a thermal exposure. To meet these requirements, strongly alkaline Na-silicates (sodium silicate) of a low modulus $(M=1.84)$, whose high strengths can be achieved with dehydration, were suggested. The influence of the chemical composition of the mixture and the modifications of the base-matrix granulometry (sample $\mathrm{NaCl}$ ) on the mean bending strength $\left(\sigma_{\mathrm{o}}\right)$ and the seeming porosity $m$ was studied in the framework of the experiment (Table 2).

The results of the measurements of the physical properties of the cores shot from pure salts with the Na-silicate binder (Table 2) showed the highest strengths for the mixture compositions III, IV (salt $\mathrm{NaCl}$, the 
original granulometry); on the contrary, the lowest bending strengths were achieved for the cores with a modified granulometry (under $0.63 \mathrm{~mm}$ and $0.4 \mathrm{~mm}$ - ground; I, II, V).

Table 2: Technological parameters of basic salt-core mixtures Tabela 2: Tehnološki parametri osnovne slane mešanice jedra

\begin{tabular}{|c|l|c|c|}
\hline Composition & \multicolumn{1}{|c|}{ Granulometry } & $m / \%$ & $\sigma_{\mathrm{o}} / \mathrm{MPa}$ \\
\hline I & $<\phi 0.63 \mathrm{~mm}$ & $46-48$ & 1.766 \\
\hline II & $<\phi 0.63 \mathrm{~mm}$ & $46-49$ & 1.794 \\
\hline III & original granulometry & $42-56$ & 2.332 \\
\hline IV & original granulometry & $47-51$ & 2.115 \\
\hline $\mathrm{V}$ & $<\phi 0.4 \mathrm{~mm}$ & $48-52$ & 1.332 \\
\hline
\end{tabular}

The seeming porosity was high in all the cases $(>42 \%)$. A high porosity of a core enables a high rate of solution in water but it is also a cause for thermal deformations (above $600{ }^{\circ} \mathrm{C}$, the plastic state) and an easy metal penetration.

Therefore, further tests led to a decrease in the porosity of the core faces (protective coatings, sintering of the surface) and an improvement in the strength characteristics by shooting the composite salts.

Additives A and B were used for the salt matrix of the composition of mixture III. The mean values of the results of the experiments determining the bending strengths of individual composite salt cores are summarized in Figure 1.

Besides decreasing the core-face porosity (by 17-23\%) neither the A additive nor the $\mathrm{B}$ one caused any required strength effect.

The bending strength ranged within 2.93-3.3 $\mathrm{MPa}$ (the density of $1.2-1.33 \mathrm{~g} / \mathrm{cm}^{3}$ ), corresponding to the values of about $25 \%$ of the bending strength of the squeezed cores.

In this development phase the cores prepared with the injection technology (WARM BOX) are only applicable in the gravity and low-pressure casting technologies.

\subsection{High-pressure squeezing of the salts}

The $\mathrm{KCl}$ salt that generally exhibits higher primary and secondary strengths compared to the $\mathrm{NaCl}$ technical salt was chosen as the salt matrix for this part of the

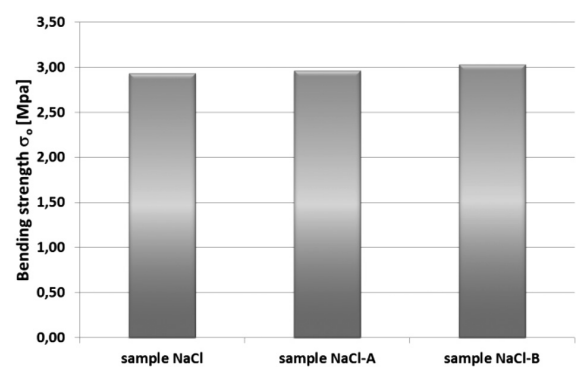

Figure 1: Bending strength of the composite salt cores prepared with the WARM-BOX method

Slika 1: Upogibna trdnost kompozitnih slanih jeder, pripravljenih po metodi WARM-BOX experiment ${ }^{5}$. The apparent porosity of the salt cores prepared with high specific pressures was up to $4 \%$; the results of the bending strength are summarized in Table 3.

Table 3: Influence of the additive on the bending strength of composite salt cores

Tabela 3: Vpliv dodatkov na upogibno trdnost kompozitnih slanih jeder

\begin{tabular}{|l|c|c|c|c|c|c|}
\hline \multirow{2}{*}{ Salt matrix KCl } & \multicolumn{2}{|c|}{$\mathrm{A} / \%$} & \multicolumn{2}{c|}{$\mathrm{B} / \%$} & \multicolumn{2}{c|}{$\mathrm{C} / \%$} \\
\cline { 2 - 7 } & 0 & 10 & 0 & 10 & 0 & 10 \\
\hline after $48 \mathrm{~h}, \mathrm{MPa}$ & 7.5 & 7.9 & 7.6 & 8.1 & 6.5 & 7.2 \\
\hline $\begin{array}{l}\text { Hot strength } \\
\left(650^{\circ} \mathrm{C}, 1 \mathrm{~h}\right), \mathrm{MPa}\end{array}$ & $>8.9$ & 13.2 & 8.9 & 10.1 & 8.1 & 8.9 \\
\hline $\begin{array}{l}\text { Residual strength } \\
\left(650^{\circ} \mathrm{C}, 1 \mathrm{~h}\right), \mathrm{MPa}\end{array}$ & 8.5 & 8.7 & 6.8 & 9.9 & 7.9 & 7.8 \\
\hline
\end{tabular}

The test showed that the use of the composite salts of a defined granulometry in combination with the $\mathrm{KCl}$ salt makes it possible to increase both the primary and secondary strengths and the thermostability of the cores too (an increase in the bending strengths under $650{ }^{\circ} \mathrm{C}$ ) which is advantageous and desirable in the high-pressure casting of Al-alloy castings. However, the questions about what changes will take place with respect to the bench life (hygroscopicity), the solubility of the composite cores and the surface quality of the pre-cast holes of the test castings as a result of the increased cooling effect of the cores (the presence of additives) remain to be answered.

\subsection{Bench life and the kinetics of solubility of the composite cores}

The hygroscopicity of salt cores (the bench life) and the solubility too belong to the key parameters of the application of salt cores. The hygroscopicity of the composite cores was measured under the conditions defined in advance, simulating the extreme conditions of storing the cores $\left(R V=100 \%, T=26{ }^{\circ} \mathrm{C}\right)$, with the additions of $30 \%$ of individual additives corresponding to the theoretical maximum concentration of an additive (the economic and technological maximum). The hygroscopicity was defined as the increase in the mass fractions (\%) in a given period of time (Table 4).

Table 4: Storability of composite salt cores

Tabela 4: Ustreznost za skladiščenje kompozitnih slanih jeder

\begin{tabular}{|c|c|c|c|c|}
\hline $\begin{array}{c}\text { Number of } \\
\text { days }\end{array}$ & $\mathrm{K}$ & $\mathrm{K}+30 \% \mathrm{~A}$ & $\mathrm{~K}+30 \% \mathrm{~B}$ & $\mathrm{~K}+30 \% \mathrm{C}$ \\
\hline 1 & 0.00 & 0.00 & 0.00 & 0.00 \\
\hline 2 & 0.01 & 0.33 & 0.36 & 0.01 \\
\hline 3 & 0.02 & 0.60 & 0.70 & 0.03 \\
\hline 17 & 0.03 & 0.72 & 0.92 & 0.04 \\
\hline 32 & 0.06 & 2.20 & 2.73 & 0.08 \\
\hline
\end{tabular}

Note: $\mathrm{K}=\mathrm{KCl}$ 


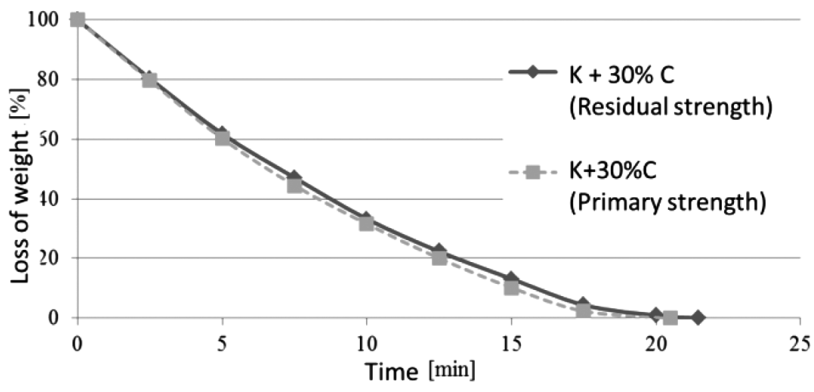

Figure 2: Solubility of composite cores (cold hardened and after thermal exposure), $\mathrm{K}=\mathrm{KCl}$

Slika 2: Topnost kompozitnih jeder (hladno utrjenih in po izpostavi toploti), $\mathrm{K}=\mathrm{KCl}$

With regard to the results of the experiment it is evident that the bench life of the salt cores, even under extreme conditions, is very good. No considerable increase in the weight of both the base salt matrix (the $\mathrm{KCl}$ sample) and the composite salt cores was observed. Only a low growth in the weight (the moisture) was observed for the cores consisting of the mixtures $\mathrm{KCl}+30 \% \mathrm{~A}$ $(2.20 \%)$ and $\mathrm{KCl}+30 \% \mathrm{~B}(2.73 \%)$.

The solubility of the salt cores was modeled with the composite salt mixture $\mathrm{KCl}+30 \% \mathrm{C}$ showing the lowest hygroscopicity during the determination of the core bench life.

The solubility of the composite salts was measured on the composite cores in water at a temperature of $20{ }^{\circ} \mathrm{C}$, namely, in the cases of the cold-hardened ones (the primary strength) and the cores after the thermal exposure $\left(650{ }^{\circ} \mathrm{C}, 1 \mathrm{~h}\right.$; the residual strength). The solubility was then defined as the weight loss of the cores in time dependence (Figure 2).

The results determining the solubility of the composite salt cores showed a high solubility of the composites (totally dissolved in up to $22 \mathrm{~min}$ ), with no differences with regard to the thermal treatment of the cores.

The whole process can be speeded up with the movement, the temperature and the water pressure; in

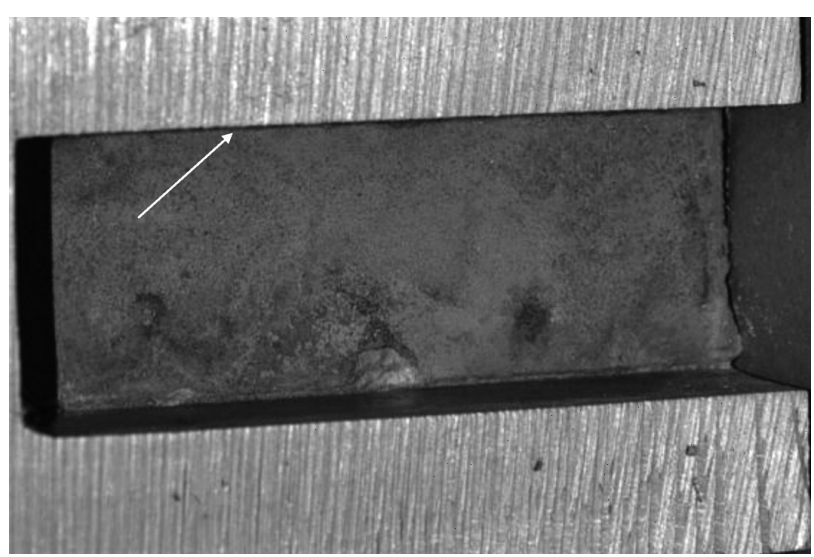

Figure 3: Area of a pre-cast hole in a model casting for a determination of the mean arithmetic roughness $R_{\mathrm{a}}$

Slika 3: Področje predizdelane odprtine na modelnem ulitku za določitev srednje aritmetične hrapavosti $R_{\mathrm{a}}$ spite of this the results showed that, during the storage, the additives or the thermally treated (up to $650{ }^{\circ} \mathrm{C}$ ) cores influence neither the dissolution kinetics nor the core hygroscopicity.

\subsection{Surface quality of the test castings}

Samples of the composite salt cores with the compositions $\mathrm{KCl}+15 \% \mathrm{~A}$ and $\mathrm{KCl}+15 \% \mathrm{C}$ prepared with the high-pressure squeezing were chosen for a determination of the surface quality of the pre-cast holes on a test casting (Figure 3). In spite of the fact that the apparent porosity of the squeezed cores was up to $4 \%$ different spirituous coatings with different fillers were used for improving of the surface quality of the castings (Table 5).

Table 5: Basic characterization of the applied coatings Tabela 5: Osnovne značilnosti uporabljenih premazov

\begin{tabular}{|c|l|}
\hline Coating & \multicolumn{1}{|c|}{ Filling agent } \\
\hline $\mathrm{a}$ & zircon silicate + aluminum silicate \\
\hline $\mathrm{b}$ & corundum \\
\hline $\mathrm{c}$ & base of zircon silicate \\
\hline
\end{tabular}

The values of the mean arithmetic roughness $R_{\mathrm{a}}$ of the test castings are summarized in Table 6. Most of the pre-cast holes show the surface roughness $\left(R_{\mathrm{a}}=\right.$ $7.5-18.6 \mu \mathrm{m})$ in dependence of the used additive and the coating, too.

Table 6: Mean arithmetic roughness of the test castings

Tabela 6: Srednja aritmetična hrapavost preizkusnih ulitkov

\begin{tabular}{|c|c|c|}
\hline Sample & Coating & $R_{\mathrm{a}} / \mu \mathrm{m}$ \\
\hline $\mathrm{K}+15 \% \mathrm{~A}$ & $\mathrm{c}$ & $7.5-10.4$ \\
\hline $\mathrm{K}+15 \% \mathrm{C}$ & $\mathrm{c}$ & 15.4 \\
\hline $\mathrm{K}+15 \% \mathrm{C}$ & $\mathrm{b}$ & 18.6 \\
\hline $\mathrm{K}+15 \% \mathrm{C}$ & $\mathrm{a}$ & 7.86 \\
\hline
\end{tabular}

The best results were achieved in the case of the squeezed composite cores $\mathrm{KCl}+15 \%$ A using coating c with the viscosity at a discharge rate of $20 \mathrm{~s}$ (F. v.).

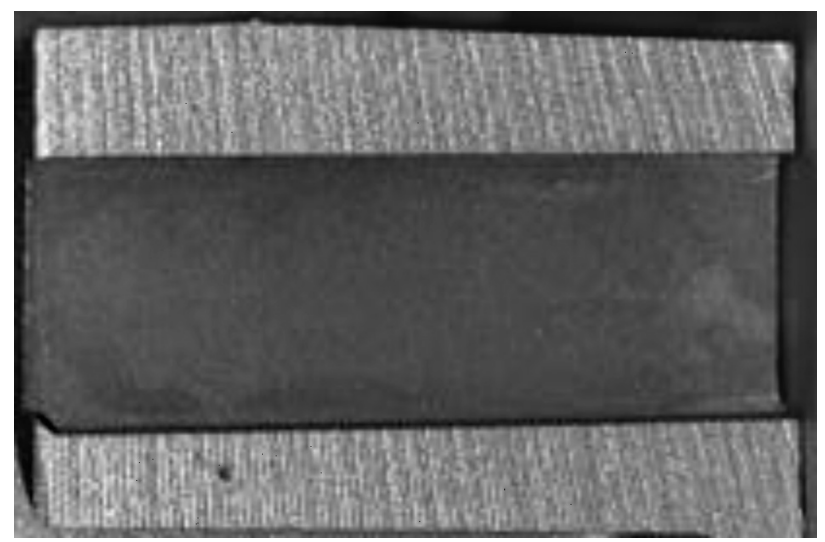

Figure 4: Detail of a test casting surface, $\mathrm{K}+15 \% \mathrm{~A}$

Slika 4: Detajl površine preizkusnega ulitka, K+15\% A 
These castings showed smooth compact surfaces without any coating residues and with the value of $R_{\mathrm{a}}$ as $7.5 \mu \mathrm{m}$ (Figure 4).

\section{CONCLUSION}

This contribution aimed at determining the influences of individual additives on the behaviour of the cores prepared with different methods (an injection and squeezing) during a production of the castings with a high surface quality of the pre-cast holes.

With regard to the results of the experiment involving the salt cores prepared with the warm-core-box method, it can be stated that, in this phase of the development, the cores prepared with this technology are applicable only for the gravity and low-pressure casting technologies.

The cores based on inorganic salts prepared with the high-pressure squeezing method show high primary and secondary strengths. Additions of additives do not influence the solubility of the salt cores (in static water it is up to $22 \mathrm{~min}$ ). The whole process can be speeded up with mechanical actions, the temperature and the water pressure. On the other hand, the additions of additives positively influence the surface roughness of the pre-cast holes of the test castings.

\section{Acknowledgement}

The research was done with the financial support of the Technological Agency of the Czech Republic within the Alfa Programme, TA 02011314.

\section{REFERENCES}

${ }^{1}$ P. Stingl, G. Schiller, Leichte und rückstandfreie Entkernung, Giesserei Erfahrungsaustausch, (2009) 6, 4-8

${ }^{2}$ P. Jelínek et al., Ověření solných jader na tlakově litém odlitku, Technológ, 4 (2013) 2, 17-22

${ }^{3}$ P. Lichý, M. Cagala, D. Žáček, Thermomechanical properties of foundry magnesium alloys, Proc. of 20th Anniversary International Metallurgical and Materials Conference METAL 2011, Ostrava, 2011, 890-896

${ }^{4}$ J. Malík, P. Futaš, I. Vasková, Š. Eperješi, Influence of technological factors of pressure die casting on quality of castings from silumin, Slévárenství, 55 (2007) 5/6, 259-262

${ }^{5}$ P. Jelínek et al., Influencing the strength characteristics of salt cores soluble in water, Slévárenství, 60 (2012) 3/4, 85-89 